\title{
Evaluation of the Properties of Healing of the Extract of Kombucha in Sheep in Growth with Malnutrition, Parasitocis and Respiratory Problems
}

\author{
Rosales Cortes Manuel1*, Albarrán Rodríguez Esther1, Nolasco Rodríguez Guillermo, \\ Raúl Leonel De Cervantes Mireles ${ }^{1}$, Leticia Ávila Figueroa ${ }^{1}$, Jesus Jonatan Iñiguez Orozco ${ }^{1}$, \\ Erika Rizo De La Peña ${ }^{2}$ \\ ${ }^{1}$ División de Ciencias Veterinarias, Centro Universitario de Ciencias Biológicas Agropecuarias de la Universidad \\ de Guadalajara, Guadalajara, México \\ ${ }^{2}$ Desarrollo de Ovinos y Caprinos del Rancho La Cofradía de la Universidad de Guadalajara, Guadalajara, México \\ Email: mrosales@cucba.udg.mx
}

Received 9 July 2014; revised 9 August 2014; accepted 19 August 2014

Copyright (C) 2014 by authors and Scientific Research Publishing Inc.

This work is licensed under the Creative Commons Attribution International License (CC BY).

http://creativecommons.org/licenses/by/4.0/

(c) (i) Open Access

\section{Abstract}

With the objective to evaluate the properties, curatives of kombucha extract as an alternative treatment were used; 20 sheep creoles weaned with stunting, respiratory diseases, parasitic and malnutrition were divided into control and experiment $n=10$ groups; the first one was administered by ivermectin $1 \%(2 \mathrm{mg} / \mathrm{kg})$ subcutaneous, with a reinforcement of closantel $5 \%(0.5 \mathrm{mg} / \mathrm{kg})$ by oral route and enrofloxacin at $5 \%(3 \mathrm{mg} / \mathrm{kg})$ intramuscularly for three consecutive days and the second group by oral route $20 \mathrm{ml}$ of extract kombucha per animal each three days for about 4 months, was weighed at the beginning of each month; clinical tests were conducted and statistical data indicated no significant differences in weight gain $30.370 \mathrm{~kg} / \mathrm{p}$ control, $31.290,3.503 \mathrm{~kg} / \mathrm{p}$ experimentally, some showed small differences in blood samples and in stool tests for example, control ended with Eimeria $1.00 \pm 0.00$, creatinine, $0.17 \pm 0.04 \mathrm{mg} / \mathrm{dl}$, uric acid $23.205 .37 \pm \mathrm{mg} / \mathrm{dl}$, 46.12 $\pm 4.70 \mathrm{MCV}, 7.21 \pm 0.25 \mathrm{~g} / \mathrm{dl}$ total protein, $38.2010 .06 \pm 1.40$ and segmented neutrophils \pm 1.07 , and on the other hand the experimental in erythrocytes present $9783000.00 \pm 1036072.17$ million, in hemoglobin $13.43 \pm 0.51 \mathrm{~g} / \mathrm{dl}$, hematocrit $38.87 \pm 2.13$, and platelet $422320.000 \pm$ $\mathbf{5 2 4 4 2 . 5 7 8}$ thousands. Both groups did not exceed normal parameters, however, physically the experimental animals were better and had no parasites or respiratory problems as opposed to controls.

\footnotetext{
${ }^{*}$ Corresponding author.
}

How to cite this paper: Manuel, R.C., et al. (2014) Evaluation of the Properties of Healing of the Extract of Kombucha in Sheep in Growth with Malnutrition, Parasitocis and Respiratory Problems. Open Journal of Veterinary Medicine, 4, $175-182$. http://dx.doi.org/10.4236/ojvm.2014.48020 


\section{Keywords}

\section{Ovine, Kombucha, Respiratory and Parasitic Problems}

\section{Introduction}

High costs and the indiscriminate use of drugs and its wrong application can become disruptive in an exploitation since they raise production costs or create cross-resistance to antibiotic with losses as reports ranging from $10 \%-15 \%$, which is not counting losses by death of animals, seizures of viscera and channels in the slaughter plants [1]-[4].

Kombucha tea is an organic and symbiotic culture of yeast and beneficial bacteria that form a zooglea (membrane gelatinous to the beginning and rubbery at the end). Their appearance is like the typical cream of household vinegar made from fruits, its composition is controversial because it is not a organism in concrete as fungi or algae may be and however is part of both, of them with a $\mathrm{pH}$ of $2.8-4$ at a temperature of $26^{\circ} \mathrm{C}$ [5]-[7].

The beneficial effects of the extract of the kombucha observed in human health are different. It was determined that kombucha regulates blood and gastric $\mathrm{pH}$ since it acts as a buffer, helps regulate the activity of the digestive tract by stimulating the motility, defecation, and the production of beneficial microorganisms. It decreases the indigestion, constipation, hemorrhoids, and favors the removed debris and impurities from the body, by their biological characteristics acts as a prebiotic, the digestion process with beneficial physiological effects on the intestine thin, thick, for the health of the host resistant microorganisms present in kombucha are within the group of micro-organism classified as probiotics such as yeasts of the genera Saccharomyces and Lactobacilli and Bifidocaterium Lactobacillus acidophilus [6]-[8].

It also has antibacterial and antimicrobial activity by the presence of usnic acid at a rate $0.65 \mathrm{~g} / 100 \mathrm{ml}$ and acetic acid $1.60 \mathrm{~g} / 100 \mathrm{ml}$, which are present in fermentation for 14 days and those mainly attack the Staphylococcus aureus, Shigellasonnei, E. colli, Aeromonas hydrophila, Yersinia enterocolitica, Pseudomonas aeruginosa, Enterobacter cloacae, Staphylococcus epidermis, Campylobacter jejuni, Salmonella enteritidis, Salmonella typhimurium Bacillus cereus, Helicobacter pylori and Listeria monocytogenes [7]-[11].

Butyric acid and glucuronic acid help to strengthen cell membranes, generally avoiding the infestation by parasites and also of kombucha yeast combat Candida group to compete with yeasts that are gradually replaced which reproduce vegetatively or by fission more for production of spores. The production of glucuronic acid at a rate of $0.38 \mathrm{~g} / 100 \mathrm{ml}$ for 14 days of fermentation helps to stabilize metabolism and detoxify when it combines or mixes with endogenous or exogenous substances that act as toxins and waste and avoid being reabsorbed by the body, therefore they are eliminated by the body's excretory system as a result increasing the body's defenses manifesting itself with vigour and a wellbeing generalized in addition to lowering cholesterol through their elimination by conjugation of the glucoronitransferasa that stimulates the gluconiridacion, also low blood pressure preventing and attacking the arteriosclerosis, a person of approximately $70 \mathrm{~kg}$ of weight can consume $60 \mathrm{ml}$ daily of kombucha extract [3]-[9].

Its benefits to cure diseases such as gout, rheumatism, arthritis, etc., presented by the excess of harmful substances deposited in the body such as uric acid, triglycerides that to be conjugated with glucuronic acid contained in kombucha are soluble in water, giving them the ability to be eliminated by the kidneys through urine, in addition the presence of this acid along with glucosamine stimulates the production of acid hyaluronic which helps to form and protect articular cartilages [2]-[9].

\section{General Objective}

Based on the healing powers that have been shown in previous studies by various authors in this work we use the extract of kombucha as an alternative treatment of low-cost and easy acquisition with the intention of stimulating the immune system, combat respiratory problems, parasitic, detoxify the body and improve the physiological conditions of the animals and that these are reflected in the weight gain and decrease of production costs.

\section{Material and Methods}

This work was carried out during four months on the premises of the Posta Zootécnica Cofradia of the Univer- 
sity of Guadalajara of Mexico in the area of production of sheep, with adlibitum access to water with high percentage of protein and free access, according to technical specifications for the production, care and use of experimental animals (Bovinos, Ovinos y Caprinos) [12].

\subsection{Experimental Design}

With laboratory tests and necropsies were previously diagnosed with infection by Pasteurella multosida, Oestrusovis, contagious ecthyma, gastrointestinal parasitic infections, growth retardation, malnutrition and poor physiological conditions were chosen 20 animals males and females recently weaned $16 \pm 2 \mathrm{~kg}$ divided in two control groups and experimental were identified and weighed at the beginning study and subsequently every month to determine weight gain, the group control applied you as products $2 \mathrm{mg} / \mathrm{kg}$ of ivermectin $1 \%$ subcutaneous and a month and a half is reinforced with $5 \mathrm{mg} / \mathrm{kg}$ of closantel $5 \%$, by oral route and for respiratory problems applied les of intramuscularly $3 \mathrm{mg} / \mathrm{kg}$ of enrofloxacin at $5 \%$ for three days. day.

Only became the experimental group a $20 \mathrm{ml}$ of kombucha extract by oral route intake per animal every third

\subsection{Coprology Analysis}

Samples of fresh excrement to the start of work and then one time per month to apply quantitative coprologica McMaster technique, using saturated $\mathrm{NaCl}$ saline solution (331 g/Lt of water), as liquid flotation to determine the number and type of paracitos were evaluated 10 fields of a $\mathrm{cm}^{2}$ per animal with a light microscope with $10 \times$ objective [10].

\subsection{Blood Chemistry}

To evaluate the behavior of the immune system in addition to the physiological status each month is made them count and blood chemistry [10].

\subsection{Statistical Analysis}

For the analysis of the results the student's t-test and sum of Mann-Whitney ranges with a significance level of 0.05, using the program Sigma Stat 3.1.

\section{Results}

It was observed that the body weight was similar at the beginning and at the end of the study no statistical differences between the groups, reason why there were no differences in weight of the two groups Table 1.

In terms of the identification of the parasite load, in Table 2, are the genera of parasites and their number, isolated larvae and eggs of the genera Eimeria, Strongyloides, Trichuiris and Monienza in general terms it found no differences in the first sampling, however, in successive surveys statistical differences were found between the control group and experimental had a lower amount of parasites by the effect of kombucha.

Table 3 are reference values and those identified in the blood chemistry determinations, found significant differences in the concentration of glucose in the months of April and may, in the concentration of creatinine in the month of June, in the content of urate in April and June, and finally, in cholesterol in March. Some of the identified values, regardless of the group, do not correspond to the reference values.

Table 4 presents the values of the biometrics hematic sheep were identified some differences but not exceed normal levels in leukocytes count in the month of March and May; in the number of erythrocytes in April, May and June; haemoglobin in March, April, May and June; in hematocrit in June and in platelets in the months of March, May, and June.

Table 5 shows of the results of differential counts of white blood cells are observed, on four dates in them that were monitored are increased neutrophils segmented with significant difference in June. It was observed a similar behavior for eosinophils.

\section{Discussion}

In relation to the weight gain in both groups behavior was the same which determined that the extract of kombucha if it gave good results as a treatment in the experimental group comparable to the treatment he received 
the group control in terms of improvement of the General conditions of the animals.

Found parasitic population was however not very high in the conditions in which animals were with low immune systems and the widespread loss of homeostasis were sufficient to impair their health and in both groups decreased.

In ruminants indicate that glucose is one of the important parameters to determine changes in energy metabolism as it is a reflection of the emotional, nutritional and endocrine status of an animal and as shown in Table 3 is increased in the first months in the control and the experimental perhaps by the parasitic infections and malnutrition faced by both groups causing alteration of hepatic metabolism.

Creatinine is formed from muscle metabolism along with the phosphocreatine and is excreted by the kidney, is related to muscle problems and kidney disorders levels that were found in animals in both cases were lower than normal values $(0.9-2 \mathrm{mg} / \mathrm{dl})$ probably due to physiological conditions and health of the animals.

Plasma proteins have different functions as the transport of substances, the maintenance of oncotic pressure, humoral immunity and the maintenance of homeostasis [13], included the albumins and globulins, their concentrations in serum are consistent, however, in the event of bleeding, parasitic infections and nutritional decompensation can be and our study shows increased by alterations of the immune system and chronic diseases who had.

Values of blood cells the number of red blood cells demonstrates low both in the control group as in the experimental, largely by the nutritional and physiological state of animals at the start of the study, there was a recovery from the second month in the experimental group, we found significant differences in the 3rd and 4th month of treatment of kombucha.

Hemoglobin is within normal levels in both groups, showing greater stability and a slight increase in the experimental group and a similar behavior was found in hematocrit, probably associated with physiological and animal health improvement in conditions.

The differential count identified widespread leukopenia, the cellular defense system is exceeded by the chronic problems of animals and can be interpreted that the support of the parasite and the antibiotic and administration of kombucha was allowed to improve the general condition of the animals.

\section{Conclusion}

In the present study, animals in poor physical condition, who had delayed growth, poor nutrition, cachexia, depression and signs of respiratory diseases in addition to ecthyma Contagiosum, disease causing various immunological disorders in animals, were chosen by what alterations the animals did in the values hematic which is offset in the experimental group with the use of extracts of kombucha according to previous studies showing a

Table 1. Body weight (kg) of control and experimental sheep, there were no statistical differences between control and experimental groups, student's t-test at a level of significance of $0.05 \%$.

\begin{tabular}{ccccc}
\hline Group & March & April & May & June \\
Control & $17.400 \pm 2.011$ & $21.000 \pm 2.261$ & $23.750 \pm 1.799$ & $30.370 \pm 3.745$ \\
Experimental & $16.200 \pm 1.476$ & $19.500 \pm 1.269$ & $23.330 \pm 2.142$ & $31.290 \pm 3.503$ \\
\hline
\end{tabular}

Table 2. Quantification of parasites in control and experimental sheep, Nd, non-detected. ( ${ }^{*}$ ) shows statistical differences between groups, Mann-Whitney level of significance of $0.05 \%$, Sigma Stat 3.1 .

\begin{tabular}{cccc}
\hline Group & March & April & May \\
& & Eimeria spp & \\
Control & $4.30 \pm 0.67^{*}$ & $3.50 \pm 0.53^{*}$ & $1.50 \pm 0.53^{*}$ \\
Experimental & $3.30 \pm 0.95$ & $1.00 \pm 0.82$ & $0.20 \pm 0.42$ \\
Control & & Strongyloides spp eggs & $0.10 \pm 0.32$ \\
\hline
\end{tabular}




\section{Continued}

\begin{tabular}{ccccc}
\hline Experimental & $3.70 \pm 0.95$ & $\mathrm{Nd}$ & $\mathrm{Nd}$ & $\mathrm{Nd}$ \\
& & Strongyloides spp larvae & \\
Control & $3.90 \pm 0.99$ & $3.30 \pm 0.82^{*}$ & $1.10 \pm 0.32^{*}$ & $\mathrm{Nd}$ \\
Experimental & $3.90 \pm 1.10$ & $\mathrm{Nd}$ & $\mathrm{Nd}$ & $\mathrm{Nd}$ \\
& & Trichuris spp eggs & $0.60 \pm 1.26$ \\
Control & $3.00 \pm 1.33$ & $1.20 \pm 0.42^{*}$ & $0.60 \pm 0.70$ & $\mathrm{Nd}$ \\
Experimental & $2.90 \pm 0.88$ & $0.60 \pm 1.26$ & $\mathrm{Nd}$ & $\mathrm{Nd}$ \\
Control & $3.30 \pm 1.16$ & Trichuris spp larvae & $1.10 \pm 0.57^{*}$ & $\mathrm{Nd}$ \\
Experimental & $3.40 \pm 0.97$ & nd & & $0.30 \pm 0.95$ \\
Control & $2.70 \pm 0.67$ & $2.70 \pm 0.67$ & $\mathrm{Nd}$
\end{tabular}

Table 3. Blood chemistry values of control and experimental sheep, Reference values taken from [10], $\left(^{*}\right)$ indicates statistical differences between groups, test t student or sum of ranks Mann-Whitney, significance level of 0.05\%, Sigma Stat 3.1.

\begin{tabular}{|c|c|c|c|c|}
\hline Group & March & April & May & June \\
\hline \multicolumn{5}{|c|}{ Blood glucosa reference values (44 - 81.2 mg/dl) } \\
\hline Control & $100.60 \pm 35.13^{*}$ & $117.40 \pm 20.32^{*}$ & $112.00 \pm 15.78$ & $43.60 \pm 11.96$ \\
\hline Experimental & $84.60 \pm 31.16$ & $95.90 \pm 15.40$ & $104.00 \pm 28.17$ & $48.50 \pm 8.83$ \\
\hline \multicolumn{5}{|c|}{ Urine creatinine reference values $(0.9$ - $2.7 \mathrm{mg} / \mathrm{dl})$} \\
\hline Control & $0.26 \pm 0.14$ & $0.20 \pm 0.07$ & $0.24 \pm 0.07$ & $0.17 \pm 0.04^{*}$ \\
\hline Experimental & $0.28 \pm 0.12$ & $0.25 \pm 0.10$ & $0.24 \pm 0.06$ & $0.25 \pm 0.07$ \\
\hline \multicolumn{5}{|c|}{ Uric acid reference values (10 - 26 mg/dl ) } \\
\hline Control & $21.60 \pm 3.98$ & $23.70 \pm 2.11^{*}$ & $22.40 \pm 2.22$ & $23.20 \pm 5.37^{*}$ \\
\hline Experimental & $20.30 \pm 2.58$ & $20.80 \pm 2.25$ & $21.00 \pm 1.63$ & $19.80 \pm 1.03$ \\
\hline \multicolumn{5}{|c|}{ Triglyceride reference values (16 - 20 mg/dl ) } \\
\hline Control & $16.20 \pm 4.10$ & $16.30 \pm 3.02$ & $17.00 \pm 1.70$ & $17.70 \pm 9.04$ \\
\hline Experimental & $18.60 \pm 5.97$ & $19.20 \pm 4.54$ & $16.80 \pm 2.35$ & $13.70 \pm 3.02$ \\
\hline \multicolumn{5}{|c|}{ Cholesterol reference values (80 - 120 mg/dl) } \\
\hline Control & $291.00 \pm 27.65^{*}$ & $110.30 \pm 41.09$ & $77.60 \pm 13.38$ & $93.80 \pm 9.02$ \\
\hline Experimental & $103.70 \pm 7.73$ & $124.20 \pm 17.47$ & $76.90 \pm 10.34$ & $90.20 \pm 6.97$ \\
\hline
\end{tabular}


Table 4. Average values and standard deviation of hematic biometry in sheep, reference values taken from [10], $\left(^{*}\right)$ indicates statistical differences between groups, test t student or sum of ranks Mann-Whitney, significance level of 0.05\%, Sigma Stat 3.1.

\begin{tabular}{|c|c|c|c|c|}
\hline Group & March & April & May & June \\
\hline \multicolumn{5}{|c|}{ Leukocytes (4.0 - 12.0 thousand) } \\
\hline Control & $3821.00 \pm 434.19$ & $5160.00 \pm 1066.35$ & $7295.00 \pm 696.58$ & $7333.00 \pm 1547.06$ \\
\hline Experimental & $4271.00 \pm 266.47^{*}$ & $5583.00 \pm 027.59$ & $8154.00 \pm 1005.02^{*}$ & $8190.50 \pm 1190.38$ \\
\hline \multicolumn{5}{|c|}{ Erythrocytes (8.0 - 15.0 million) } \\
\hline Control & $4199000.00 \pm 459890.08$ & $45000.00 \pm 1202416.54 \quad 7$ & $7750000.00 \pm 1053301.687$ & $7639200.00 \pm 867490.48$ \\
\hline Experimental & $4417700.00 \pm 326128.14$ & $11200.00 \pm 664671.14^{*} \mathrm{~s}$ & $9827100.00 \pm 1120908.20^{*}$ & $9783000.00 \pm 1036072.17^{*}$ \\
\hline \multicolumn{5}{|c|}{ Hemoglobin (9 - 15 g/dl) } \\
\hline Control & $13.16 \pm 0.97^{*}$ & $12.180 \pm 0.51$ & $12.29 \pm 0.93$ & $11.82 \pm 0.79$ \\
\hline Experimental & $11.59 \pm 1.07$ & $13.39 \pm 0.67^{*}$ & $14.08 \pm 1.60^{*}$ & $13.43 \pm 0.51^{*}$ \\
\hline \multicolumn{5}{|c|}{ Hematocrit (27\% - 45\%) } \\
\hline Control & $37.10 \pm 4.41$ & $36.55 \pm 2.11$ & $36.75 \pm 3.30$ & $34.87 \pm 2.87$ \\
\hline Experimental & $40.21 \pm 3.74$ & $36.30 \pm 3.11$ & $41.12 \pm 5.75$ & $38.87 \pm 2.13^{*}$ \\
\hline \multicolumn{5}{|c|}{ MCH (8 - 12 pg) } \\
\hline Control & $20.10 \pm 8.82$ & $15.68 \pm 1.68$ & $15.14 \pm 1.85$ & $15.57 \pm 1.79$ \\
\hline Experimental & $15.00 \pm 2.05$ & $15.62 \pm 1.93$ & $13.92 \pm 2.09$ & $14.12 \pm 2.51$ \\
\hline \multicolumn{5}{|c|}{$\operatorname{MCV}(23$ - 48 fL) } \\
\hline Control & $42.60 \pm 4.40$ & $47.25 \pm 5.02$ & $45.94 \pm 5.76$ & $46.18 \pm 4.70^{*}$ \\
\hline Experimental & $44.90 \pm 4.38$ & $47.16 \pm 5.07$ & $41.33 \pm 5.22$ & $39.31 \pm 5.72$ \\
\hline \multicolumn{5}{|c|}{ MCHC (31 - 34 rg/dl) } \\
\hline Control & $33.22 \pm 0.28$ & $33.27 \pm 2.17$ & $33.05 \pm 0.30$ & $33.86 \pm 2.18$ \\
\hline Experimental & $33.28 \pm 0.29$ & $33.10 \pm 0.87$ & $33.10 \pm 0.60$ & $33.28 \pm 0.73$ \\
\hline \multicolumn{5}{|c|}{ Platelets (220 - 680 thousand) } \\
\hline Control & $444900.000 \pm 68121.54$ & $311400.000 \pm 47103.196$ & $66361600.000 \pm 150795.815$ & $293500.00 \pm 28741.18$ \\
\hline Experimental & $522200.000 \pm 98271.506^{*}$ & $331100.00 \pm 74036.70$ & $402520.000 \pm 51541.500^{*}$ & $422320.000 \pm 52442.578^{*}$ \\
\hline \multicolumn{5}{|c|}{ Total protein (6 - 7.5 gr/dl) } \\
\hline Control & $8.25 \pm 0.41$ & $8.27 \pm 0.46^{*}$ & $7.48 \pm 0.43$ & $7.21 \pm 0.25^{*}$ \\
\hline Experimental & $8.33 \pm 0.28$ & $7.41 \pm 0.43$ & $6.70 \pm 0.82$ & $6.54 \pm 0.57$ \\
\hline
\end{tabular}


Table 5. Differential white blood cell count and standard deviation, Reference values taken from [10], $\left(^{*}\right)$ indicates statistical differences between groups, test t student or sum of ranks Mann-Whitney, significance level of 0.05\%, Sigma Stat 3.1.

\begin{tabular}{|c|c|c|c|c|}
\hline Group & March & April & May & June \\
\hline \multicolumn{5}{|c|}{ Segmented neutrophils (reference values $\mathbf{4 0 . 5 \% )}$} \\
\hline Control & $21.10 \pm 5.10$ & $19.80 \pm 4.80$ & $29.10 \pm 6.62$ & $38.20 \pm 10.06^{*}$ \\
\hline Experimental & $38.50 \pm 11.62^{*}$ & $19.10 \pm 2.72$ & $32.00 \pm 5.51$ & $29.30 \pm 5.14$ \\
\hline \multicolumn{5}{|c|}{ Banded neutrophils (reference values $0 \%-2 \%$ ) } \\
\hline Control & $1.20 \pm 1.22$ & $0.80 \pm 0.63$ & $0.50 \pm 0.70$ & $0.20 \pm 0.42$ \\
\hline Experimental & $0.40 \pm 0.69$ & $0.80 \pm 0.78$ & $0.20 \pm 0.42$ & $0.30 \pm 0.48$ \\
\hline \multicolumn{5}{|c|}{ Eosinophils (reference values $3.8 \%$ - $6.3 \%$ ) } \\
\hline Control & $5.60 \pm 1.77$ & $6.10 \pm 2.33$ & $2.90 \pm 1.44^{*}$ & $1.40 \pm 1.07^{*}$ \\
\hline Experimental & $5.10 \pm 1.44$ & $4.80 \pm 1.98$ & $1.00 \pm 1.15$ & $0.50 \pm 0.97$ \\
\hline \multicolumn{5}{|c|}{ Lymphocytes (reference values $42 \%$ - $64 \%$ ) } \\
\hline Control & $54.90 \pm 9.44$ & $69.20 \pm 4.75$ & $65.40 \pm 6.05$ & $59.30 \pm 9.78$ \\
\hline Experimental & $54.40 \pm 10.75$ & $73.80 \pm 2.70^{*}$ & $66.50 \pm 7.04$ & $65.70 \pm 6.60$ \\
\hline \multicolumn{5}{|c|}{ Monocytes (reference values $1.77 \%-5.5 \%$ ) } \\
\hline Control & $1.50 \pm 1.26$ & $2.80 \pm 1.98$ & $1.90 \pm 1.79$ & $1.90 \pm 1.79$ \\
\hline Experimental & $1.60 \pm 1.83$ & $1.70 \pm 1.70$ & $1.50 \pm 2.12$ & $1.90 \pm 1.66$ \\
\hline \multicolumn{5}{|c|}{ Basophils (reference values $0.07 \%$ - $0.06 \%$ ) } \\
\hline Control & Nd & $\mathrm{Nd}$ & $\mathrm{Nd}$ & Nd \\
\hline Experimental & $\mathrm{Nd}$ & $\mathrm{Nd}$ & $\mathrm{Nd}$ & $\mathrm{Nd}$ \\
\hline
\end{tabular}

beneficial effect by having activity antibacterial, antiparasitic, antifungal, anti-allergic and stimulating the immune system in addition to detoxifying the body, on the other hand in the group control was necessary as well as de-worming medications with poor results.

\section{References}

[1] Castells, D. (2002) Nuevo enfoque en el control parasitario de ovinos (Resistencia genética del ovino y su aplicación en sistemas de control integrado de parásitos. Dirección de Producción y Sanidad Animal). Animal Production and Health Paper, Roma, 17-24.

[2] Clegg, D.O., Reda, D.J. and Harris, C.L. (2006) Glucosamine, Chondroitin Sulfate, and the Two in Combination for Painful Knee Osteoarthritis. The New England Journal of Medicine, 354, 795-808.

[3] Cvetkovic, D. and Markov, S. (2002) Cultivation of Tea Fungus on Malt Extract Medium. Acta Periodica Technologica, 33, 117.

[4] FAO (2002) Food Agriculture Organization Network for Helminthology in Africa. Global Escalation of Anthelmintic Resistance (AR) Calls for a Re-Evaluation of the Problem.

[5] Jayabalan, R., Marimuthu, S. and Swaminathan, K. (1995) Changes in Content of Organic Acids and Tea Polyphenols during Kombucha Tea Fermentation. Food Chemistry, 102, 392-398.

[6] Gibson, G.R. and Roberfroid, M.B. (1995) Dietary Modulation of the Human Colonic Microbiota: Introducing the Concept of Prebiotics. Journal of Nutrition, 125, 1401-1412.

[7] Greenwalt, C.J., Steinkraus, K.H. and Ledford, R.A. (2000) Kombuchathe Fermentated Tea Microbiology Composition and Claimed Health Effect. Journal of Food Protection, 63, 976-981.

[8] Kanurić Katarina, G., Hrnjez Dajana, V., Ranogajec Marjan, I., Milanović Spasenija, D., Iličić Mirela, D., Vukić Vladimir, R. and Milanović Maja, L.J. (2011) The Effect of Fermentation Temperature on the Functional Dairy Prod- 
uct Quality. Acta Periodica Technologica, 42, 63-70. http://dx.doi.org/10.2298/APT1142063K

[9] Yavari, N., Assadi, M.M., Larijani, K. and Moghadam, M.B. (2010).Response Surface Methodology for Optimization of Glucuronic Acid Production. Using Kombucha Layer on Sour Cherry Juice. Australian Journal of Basic and Applied Sciences, 4, 3250-3256.

[10] Rivera, A.J.A. (2006) Técnicas de laboratorio para el diagnóstico veterinario. Manual para obtener el titulo de Médico Veterinario Zootecnista, Villahermosa.

[11] Sreeramulu, G., Zhu, Y. and Knol, W. (2000) Kombucha Fermentation and Its Antimicrobial Activity. Journal of Agricultural and Food Chemistry, 48, 2589-2594.

[12] Thrall, M.A. (2007) Hematologia y Bioquímica Clínica Veterinária. 1st Edition, Roca, São Paulo.

[13] UNAM (2001) Especificaciones técnicas para la producción cuidado y uso de los animales de experimentación en rumiantes (Bovinos, Ovinos y Caprinos). 
Scientific Research Publishing (SCIRP) is one of the largest Open Access journal publishers. It is currently publishing more than 200 open access, online, peer-reviewed journals covering a wide range of academic disciplines. SCIRP serves the worldwide academic communities and contributes to the progress and application of science with its publication.

Other selected journals from SCIRP are listed as below. Submit your manuscript to us via either submit@scirp.org or Online Submission Portal.
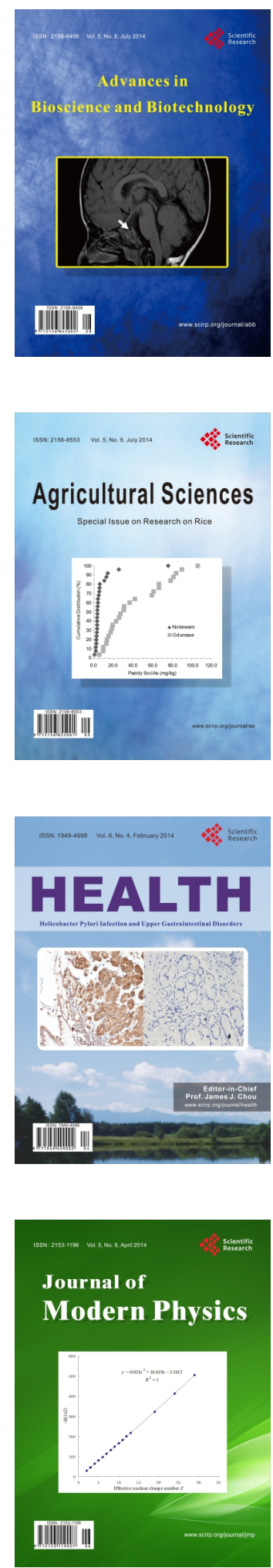
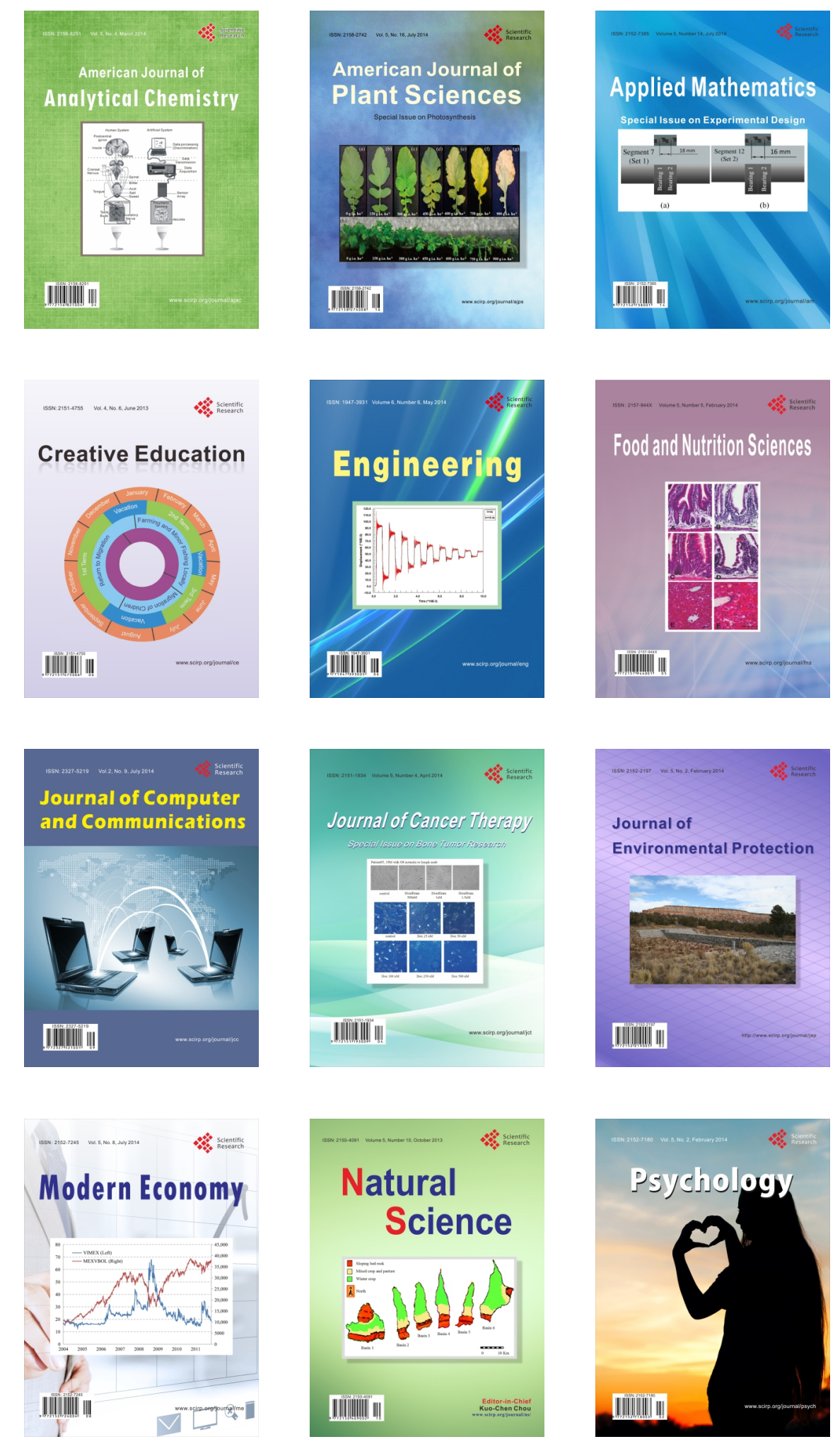